\title{
Microdosing technology of fertilizer for sorghum production at Shambat, Sudan
}

\author{
MONIRAH BABIKER MOHAMED ARBAB, YASSIN MOHMAD IBRAHIM DAGASH" \\ Department of Agronomy, College of Agricultural Studies, Sudan University of Science and Technology. Shambat, Khartoum, Sudan. ^email: \\ dagash501@gmail.com
}

Manuscript received: 4 May 2017. Revision accepted: 19 June 2017.

\begin{abstract}
Arbab MBM, Dagash YMI. 2017. Microdosing technology of fertilizer for sorghum production at Shambat, Sudan. Cell Biol Dev 1: 18-22. The study was conducted at the experimental farm of Sudan University of Science and Technology, College of Agricultural Studies; Khartoum North-Shambat, to investigate the agronomic response and efficiency of fertilizer microdosing in Sorghum. An experiment with the following treatments was achieved: control without fertilizer, microdosing treatments with the rates of $1,2,3$, and 4 g NPK per plant hole at sowing. The treatments were arranged in a completely randomized block design with four replications. The experiment was conducted during the growing season of 2015. Weeding was carried out after three weeks of seed germination and irrigated weekly. The following parameters were considered during experimentation; the number of leaves, plant height, node length, and stem thickness, while the shoot fresh and dry weights were recorded at termination. The data collected were subjected to analysis of variance, and Duncan's multiple separated the means rang test. The results obtained showed the progressive improvement of all Sorghum tested characters. There were significant differences in plant height, stem thickness, and shoot fresh and dry weight. In addition, the number of leaves and the node length showed significant differences. The four-gram microdose gave the best results.
\end{abstract}

Keywords: Microdosing, technology, fertilizer, Sorghum

\section{INTRODUCTION}

Sorghum (Sorghum bicolor L.) Moench; is the world's fifth most commonly grown cereal crop after wheat, rice, maize, and barley Poehlman (1994). Sorghum has wide cultivated varieties, such as grain genotypes, fodder, fiber and sugar genotypes, and dual-purpose genotypes. Sorghum belongs to the C4 plant characteristic for tolerating biotic stresses more than many crops Gnansounou et al. 2005. Recently, Sorghum has received significant attention because of its newer use as a Biofuel feedstock (Paterson 2008). Assessment of the genetic variability within cultivated crops and varieties has a strong impact on plant breeding strategies and conservation of genetic resources (Dean et al. 1999; Simioniuc et al. 2002) and is particularly useful in the characterization of individuals, accessions, and cultivars in germplasm collections and for the choice of parental genotypes in breeding programs (Davila et al. 1998; Ribaut et al. 1998). In the past, indirect estimates of similarity based on morphological information have been widely used in many species, including Sorghum (Ayana 1999). However, morphological variation does not reflect the real genetic variation because of genotype-environment interactions and the largely unknown genetic control of poly-genetically inherited morphological and agronomic traits (Smith and Smith 1992).

Molecular analyses in conjunction with the morphological and agronomic evaluation of germplasm are recommended because these provide complementary information and increase the resolving power of genetic diversity analyses (Singh et al. 1991). Land degradation affects more than half of Africa, leading to the loss of an estimated 42 billion dollars and 5 million hectares of productive land each year. In addition, most farmlands produce poor yields due to poor farming techniques (nutrient deficiency and irregular watering) (ICRISAT 2009).

The decline in fertility of croplands is the basis of household food insecurity, especially among the poor peasants who are the most numerous in agriculture in the Sudan region of Mali. According to Sime and Aune (2014), the fallow, the traditional way to restore the fertility of the land, has almost disappeared in some places. In others, its duration was significantly reduced because of demographic pressure. The technical packages to sustainably increase production are not within their reach. Since the 1980s, there has been a decline in public funding in agriculture and paralysis of the sector of small producers in developing countries because of the structural adjustment policies of the IMF and the World Bank (Azoulay and Saizal 1994; FAO 1995; World Bank 2007).

Many governments in sub-Saharan Africa have improved agricultural productivity by creating agricultural extension services. But these creations have not fulfilled farmers' expectations, mainly for rural women (FAO 2008). The development of sub-Saharan agriculture took from that moment an approach for the identification of technical innovation and communication, giving the farmers more space to develop appropriate strategies for development. The farmer field school is one of these strategies lying in the extension approach of bottom-up, allowing farmers to 
join the basis for understanding what to achieve in finding appropriate solutions to their development issue. It was piloted in 90 countries and reached 10 to 15 million farmers worldwide (Waddington et al., 2014). There are a lot of results on the evaluation of farmer field schools: Togola et al. (2010), FAO (2011), Braun et al. (2006), Feder et al. (2004), and Piyadasa (2005). However, there are a few contradictory results on technology diffusion from a farmer field school in sub-Saharan Africa (Davis 2006; Baah 2007).

The microdose technology is the application of small mineral fertilizer doses in the seed hole during sowing or next to the seedling after emergence (10 days after sowing). As reported by Agricultural technologies of Borkina Faso (2010), the advantages of this technology are; (i) Location of the fertilizer near the root, thus obtaining a high concentration area which makes assimilation of nutrients easier. (ii) To limit phosphorus fixation phenomena by the soil. (iii) To reduce loss of Potassium (K) and Nitrogen (N) through leaching. (iv) To achieve an early start of plant growth. (v) To increase the efficiency of fertilizer used. (vi) To minimize production cost. (vii) To improve small producers' income. (viii) To increase the number of mineral fertilizer users.

However, ICRISAT (2009) mentioned some difficulties with this technology, which include: (i) The technology is time-consuming, laborious, and difficult to ensure each plant gets the right dose. (ii) Access to fertilizer, access to credit, insufficient information flow, and appropriate training policies for the farmers. (iii) Adopting the technology requires supportive and complementary institutional innovation and input and output market linkage.

As mentioned by many researchers, the technology uses only about one-tenth of the amount typically used on wheat and one-twentieth of the amount used on corn in the USA. Yet, the African crops are so starved of nutrients such as phosphorus, potassium, and nitrogen that the micro amount often doubles crop yields (Bationo et al., 2015; Bielder, 2015).

This study also investigates if people are more likely to adopt the technology if they receive it free of charge and how knowledge passes from farmers via social networks. Thus, the study aimed to fulfill the following objectives: (i) To test the response of Sorghum to microdosing practices under Shambat clay soils. (ii) To determine suitable microdosing levels that lead to an increase in vegetative yield and, finally, the seed. (iii) To minimize the cost of fertilizer application by the plant's minimum dose of fertilizer with maximum utilization.

\section{MATERIALS AND METHODS}

\section{Experimental site and treatment}

A field experiment was conducted at the demonstration farm of the College of Agricultural Studies, Sudan University of Science and Technology, Shambat Khartoum North, (Latitude 15.40 N., 32, 32 E., elevation $380 \mathrm{~m}$ above Sea level). The climate is semi-desert with low relative humidity, an annual rainfall rate of $150 \mathrm{~mm}$, and a mean temperature of $\left(20.3 \mathrm{C}-36.1^{\circ} \mathrm{C}\right)$ and clay soil Celtic $\mathrm{pH} 7.5$ 8.7 Abdulha Feez (2001).

\section{Plant material and treatments}

The plant material was a local variety of Sorghum (Sorghum bicolor L.) obtained from the College of Agricultural Studies, Sudan University of Science and Technology (Shambat). This plant was treated by using four-level treatment, i.e., control (without fertilizer; M0), 1 g compound fertilizer microdosing (M1), 2 g compound fertilizer microdosing (M2), $2 \mathrm{~g}$ compound fertilizer microdosing (M3), and $4 \mathrm{~g}$ compound fertilizer microdosing (M4) in a randomized complete block design (RCBD).

\section{Cultural practice}

The experimental site was disc plow and harrowed, followed by harrowing, leveling, and riding up NorthSouth. The spacing between ridged was $70 \mathrm{~cm}$. Five replications were divided into four plots; each plot was $3 \times 3$, consisting of five rows. The sowing date was in December 2015, and the seeds were sown in holes, each 40 $\mathrm{cm}$ apart, and the seed was sown at a depth of $20 \mathrm{~cm}$. With fertilizer in the same hole. Weeding was done two times after, three weeks from sowing and one month from the first-hand weeding. After that, the plants were watered according to their need.

\section{Data collection}

Observations were conducted on agronomical traits. Every agronomical trait was observed by selecting five Sorghum plants randomly from each plot except $50 \%$ days to flowering. The $50 \%$ days to flowering was observed by recording the duration from planting to $50 \%$ of the plant population was blooming. Plant height was measured from the soil surface to the tip of the flag leaf using a measuring tape. The number of leaves per plant was observed by counting the average number per plant. The length of the inter-node was measured from one node to another node. Stem diameter was measured using a strip and a ruler, and then the mean stem diameter per plant was estimated. Forage fresh yield per plant was measured by weighing the plant. Forage dry yield per plant was measured by drying the plant in the oven $\left(80^{\circ} \mathrm{C}\right)$ for 48 hours and then weighing the plant.

\section{Statistical analysis}

The data were analyzed according to the standard statistical procedure for a randomized complete block design described by Gomez and Gomez (1984) using the MSTAT-C computer package. The means were separated by Duncan Multiple Range Test (DMRT).

\section{RESULTS AND DISCUSSION}

\section{Results}

The results of the study for all tested parameters are indicated in (Table 1) and separate detailed figures from (1- 
6). According to (Table 1), the results revealed that there are highly significant differences among the treatments for the plant height, stem thickness, and shoot fresh and dry weights. At the same time, there is a significant difference in the node length and number of leaves. The coefficient of variation for all tested parameters ranged between 3.73$14.47 \%$. The plant height was higher for the $3 \mathrm{~g}$ microdose treatment $(136 \mathrm{~cm})$ and the lowest for the control $(108 \mathrm{~cm})$. Figure 1 revealed a higher plant height for $3 \mathrm{M}$ followed by $2 \mathrm{M}$, but generally, the difference was not big. The highest node length was recorded for a $4 \mathrm{~g}$ microdose $(16 \mathrm{~cm})$, while the control resulted in the lowest value $(12.5 \mathrm{~cm})$. Figure 2 showed a consistent node length for $4 \mathrm{M}$ and $3 \mathrm{M}$, but $1 \mathrm{M}$ was higher than $2 \mathrm{M}$.
The best number of leaves was obtained from the $4 \mathrm{~g}$ microdose treatment, and the lowest was recorded for the control; figure 3 for the number of leaves favored was $4 \mathrm{M}$, followed by $2 \mathrm{M}$ and $3 \mathrm{M}$. The $4 \mathrm{~g}$ microdose treatment resulted in the best stem thickness $(4.36 \mathrm{~cm})$, and the lowest value was recorded for the control $(2.63 \mathrm{~cm})$. Figure 4 represents the stem thickness following the normal distribution from the high to the low $4 \mathrm{M}, 3 \mathrm{M}, 2 \mathrm{M}, 1 \mathrm{M}$, and $0 \mathrm{M}$. The highest values of shoot fresh and dry weights were recorded from the $4 \mathrm{~g}$ microdose treatment (125 and $54.50 \mathrm{~g})$, while the lowest values were obtained from the control (49.5 and $20.5 \mathrm{~g}$ ), respectively. Figures 5 and 6) for the fresh and dry weights favored $4 \mathrm{M}$ followed by $3 \mathrm{M}$.

Table 1. Summary of ANOVA (F. value) of Sorghum bicolor on micro dose experiment.

\begin{tabular}{lccccccc}
\hline $\begin{array}{c}\text { Source of } \\
\text { variation }\end{array}$ & $\begin{array}{c}\text { Degree of } \\
\text { freedom }\end{array}$ & $\begin{array}{c}\text { Plant height } \\
(\mathbf{c m})\end{array}$ & $\begin{array}{c}\text { Node length } \\
(\mathbf{g})\end{array}$ & $\begin{array}{c}\text { Number of } \\
\text { leaves }\end{array}$ & $\begin{array}{c}\text { Stem thickness } \\
(\mathbf{c m})\end{array}$ & $\begin{array}{c}\text { Shoot fresh } \\
\text { weight }(\mathbf{g})\end{array}$ & $\begin{array}{c}\text { Shoot dry } \\
\text { weight }(\mathbf{g})\end{array}$ \\
\hline Replication & 3 & 0.4996 & 3.2727 & 0.9057 & 1.1211 & 1.2496 & 0.6128 \\
Fertilizer & 4 & $36.9939 * *$ & $4.9773^{*}$ & $5.3774 *$ & $15.1966^{* *}$ & $237.4937^{* *}$ & $57.1195 * *$ \\
Error & 12 & - & - & - & - & - & - \\
Total & 19 & - & - & - & - & - & - \\
LSD 5\% & - & 5.94 & 1.80 & 0.98 & 0.51 & 5.73 & 5.18 \\
CV $(\%)$ & - & 3.73 & 8.53 & 8.31 & 10.08 & 9.41 & 14.47 \\
\hline
\end{tabular}

$\mathrm{Ns}=$ not significant, $*$ Significant $(5 \%), * *$ highly significant $(1 \%)$,

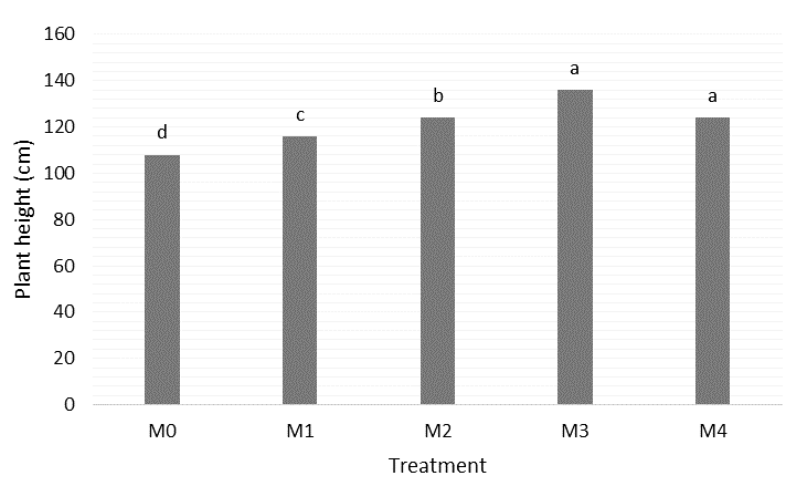

Figure 1. Effect of microdosing on sorghum plant height

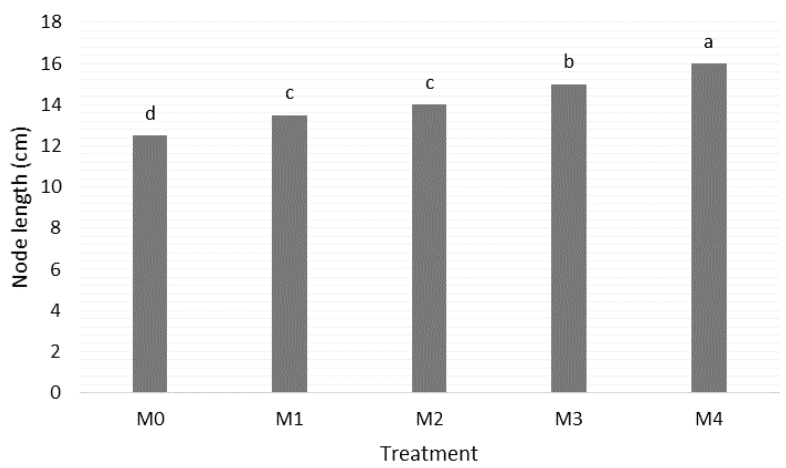

Figure 2. Effect of microdosing on sorghum node length

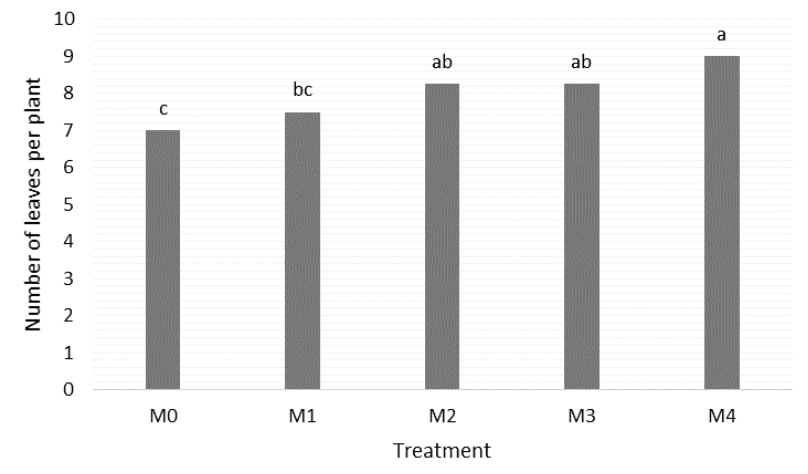

Figure 3. Effect of microdosing on number of leaves per plant of Sorghum

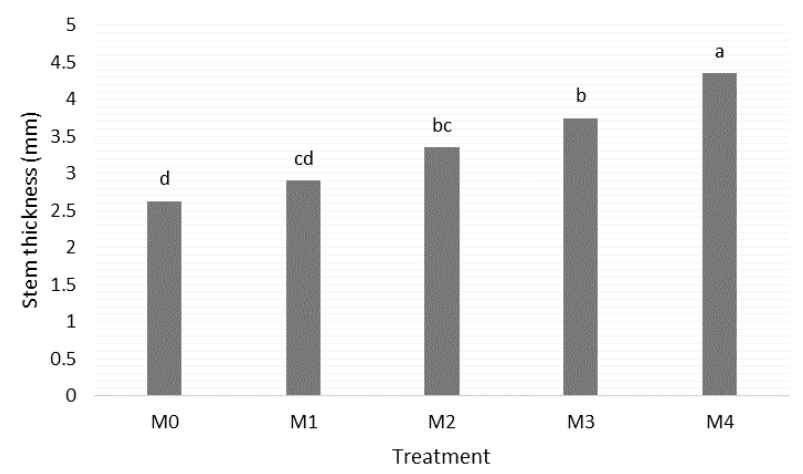

Figure 4. Effect of microdosing on sorghum stem thickness 


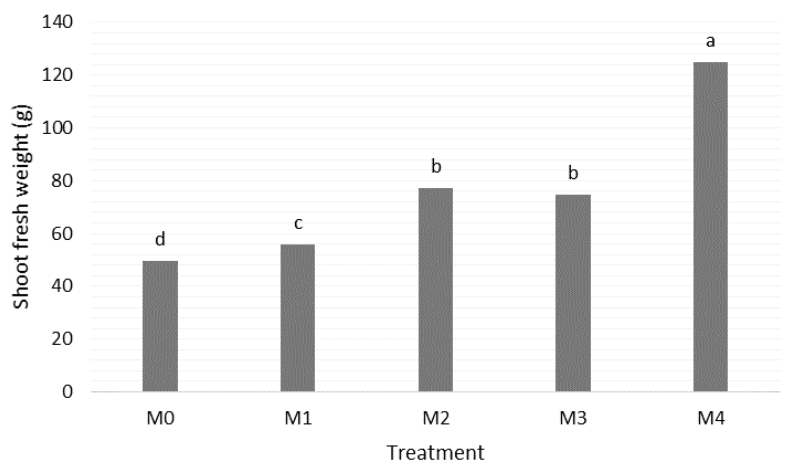

Figure 5. Effect of microdosing on fresh shoot weight of Sorghum

\section{Discussion}

Irrespective of different adverse conditions in the study site during the experimentation, all of the fertilizer rates (microdosing) increased yields compared to the control. That shows a need for fertilizer in Sorghum production in most soils of our country. An efficient fertilizer application method with a smaller fertilizer is the most important for marginal farmers in central Sudan. Such a method will potentially increase farmers' interest, economic viability, and sustainability concerning applying fertilizer to Sorghum. In this respect, the results of this study showed that the microdosing method of fertilizer application was found to improve Sorghum yields with smaller quantities of fertilizer. The study results strongly agree with Khatam et al. 2013; Morris et al. (2007).

Previous studies on the response of Sorghum and pearl millet reported by Palé et al. (2009); Vitale and Sanders (2005) had also shown similar effects that lower fertilizer rates increased crop yields more than the higher rates in microdosing in sub-Saharan countries. In as much as the results of the study concerning the adoption of microdose technology reported by Agricultural Technologies in Burkina Faso (2010) showed that the lowest fertilizer rate in microdosing was able to improve sorghum yield more than that of broadcasting in sub-Saharan countries. Similar results were also reported by Bationo (1998); Bagayoko et al. (1996) as they concluded that the cereals, in general, revealed a lower yield response to the highest fertilizer rate in microdosing, and this can be owed that there is a limit to the dose of fertilizer that can be applied through microdosing. They also noticed that the high fertilizer levels were found to depress pocket seed germination and lower plant population at harvest. These negative effects on maize performance might be attributed to the burning effects of high doses of fertilizer in the microdosing method of application. Such remarks were also reported by Druilhe and Jesús (2012), FAOSTAT (2011), and Coulibaly et al. (2000).

Therefore, if the farmers practice microdosing, they can obtain a good yield at a low fertilizer application rate. Yet, a further study based on long-term data is required to rectify optimum fertilizer rates for the different sites of

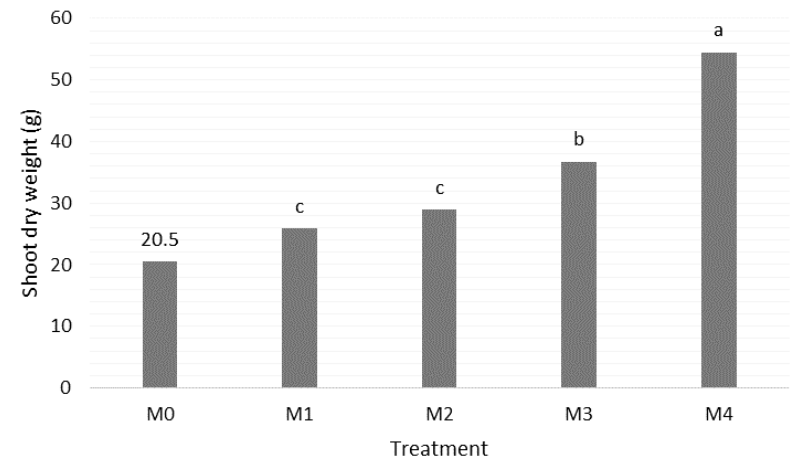

Figure 6. Effect of microdosing on dry shoot weight of Sorghum

sub-Sahelian countries depending on soil quality and other governing agroecological conditions.

As a result, the microdosing method of fertilizer application becomes more efficient in increasing the yield of cereals than the banding and broadcasting method of fertilizer application. That might be because placing fertilizer close to the seed in soils increases crop uptake, as reported by (FAOSTAT 2011). That indicates that under a better soil management system and favorable seasonal rainfall conditions, farmers can still get reasonable crop yields through microdose technology. However, the labor demand in microdosing ( 4.8 person-days ha-1) is nearly twice that in banding (2.3 days ha-1) for applying fertilizers; the microdosing method still appears attractive and viable. Like in several other areas in Ethiopia, the opportunity cost for labor is low in the central rift valley.

In conclusion, 4M (4 g microdosing) revealed the best results for most parameters and is more productive and profitable. However, generally, microdosing followed the normal pattern from the high to the low. Therefore it is recommended to use $4 \mathrm{M}$ microdosing.

\section{REFERENCES}

Agricultural Technologies in Burkina Faso. 2010. Management of Natural Resources in Burkina Faso. UA-SAFGRAD. Burkina Faso.

Ayana A, Bekele E. 1999. Multivariate analysis of morphological variation in Sorghum (Sorghum bicolor (L.) Moench) germplasm from Ethiopia and Eritrea. Genet Res Crop 46: 24-36.

Azoulay G, Saizal R. 1994. Réforme de politique économique en Afrique subsaharienne dans les années 80 et performance du secteur agricole. Etude FAO/ Développement économique et social 129/202, Rome.

Baah F. 2007. Meeting the information needs of Ghanaian cocoa farmers: are farmer field schools the answer? J Sci Technol 27 (3): 163-173.

Bagayoko M, Mason SC, Traore S, Eskridge KM. 1996. Pearl millet /cowpea cropping system yields and soil nutrient levels. Afr Crop Sci J 4 (4): 453-462.

Bationo A, Sogodogo D, Mamado G, Taonada JS, Mahaman S. 2015. The fertilizer microdose Technology. Burkina Faso.

Bationo A. 1998. Research on nutrient flows and alleviation of soil fertility of dry lands. African J Agric Res 6 (14):41-50.

Bielder C. 2015. Microdose Fertilizer: a step on the ladder towards crop intensification in the Sahel. Earth and Life Institute, Louvre, Belgum.

Braun A, Jiggins J, Röling N, Berg H. van den, Snijders P. 2006. A Global Survey and Review of Farmer Field School Experiences. Report 
prepared for the International Livestock Research Institute (ILRI). Endelea, Wageningen, The Netherlands.

Coulibaly A, Bagayoko M, Traore S, Mason SC. 2000. Effect of cropping cowpea and Sorghum on a West African soil. J Agric Sci 135: 399401.

Davila JA, Sanchez de la Hoz MO, Loarce Y, Ferrer E. 1998. DNA and coefficients of parentage to determine genetic relationships in barley. Genome 41: 477-486.

Davis K. 2006. Farmer Field Schools: A Boon or Bust for Extension in Africa? J Intl Agric Exten Educ 13 (1): 91-97.

Dean RE, Dahlberg JA, Hopkins MS, Mitchell CV, Kresovich S. 1999. Genetic redundancy and diversity among 'orange' accessions in the U.S. national sorghum collection as assessed with simple sequence repeat (SSR) markers. Crop Sci 39: 1215-1221.

Druilhe Z, Jesús BH. 2012. Fertilizer subsidies in sub-Saharan Africa. FAO, Rome.

FAO. 1995. Politique d'ajustement structurel et de stabilisation et sécurité alimentaire. Intl J Curr Microbiol App Sci 5 (4): 698-704.

FAO. 2008. L'accès des femmes à la terre en Afrique de l'Ouest: problématique et pistes de solutions au Sénégal et au Burkina Faso. Mbour, 2-4 Juillet 2008.

FAO. 2011. L'approche 'champs écoles' permet aux petits producteurs du Mali de s'adapter aux changements climatiques/ Journal New Agriculturist. Cas d'études publiés pour la journée de l'Agriculture et du développement rural-Durban-Afrique du Sud/3 décembre 2011.

FAOSTAT. 2011. Top production-West Africa (Total)-2008. FAO, Rome.

Feder G, Murgai R, Quizon JB. 2004. The acquisition and diffusion of knowledge: the case of pest management training in farmer field schools, Indonesia. J Agric Econ 55 (2): 221-243.

Gnansounou E, Dauriat A, Wyman C. 2005. Refining sweet sorghum to ethanol and sugar: economic trade-offs in the context of North China. Bioresour Technol 96: 985-1002.

ICRISAT. 2009. International Crops Research Institute for the Semi Arid Tropics. Fertilizer Microdosing Boosting Production in unproductive lands. ICRISAT, India.
Khatam A, Muhammad S, Ashraf I. 2013. Farmers' field school: a strategy for benefiting resource poor farmers in Khyber Pakhtunkhwa, Pakistan. J Anim Plant Sci 23 (6): 1749-1753.

Morris M, Kelley VA, Kopicki RJ, Byerlee D. 2007. Fertilizer use in subSahelian regions. J Agric Sci 88: 12-16.

Palé S, Mason SC, Taonda SJB. 2009. Water and fertilizer influence and residue management of cropping systems for pearl millet and cowpea yield. Afr Crop Sci J 8 (4): 1-8.

Paterson AH. 2008. Genomics of Sorghum. Intl J Plant Genom DOI: $10.1155 / 2008 / 362451$

Piyadasa M, Karltun E, Olsson M. 2005. Soil organic matter dynamics after deforestation along a farm field chronosequence in southern highlands of Ethiopia. Agric Ecosyst Environ 109: 9-19.

Ribaut JM, Hoisington D. 1998. Marker assisted selection: New tools and strategies. Trends Plant Sci. 3: 236-239.

Sime DF, Aune KR. 2014. Response of Zea maize to microdose application levels. Ethiopian Agric J 25:24-28.

Simioniuc D, Uptmoor R, Friedt W, Ordon F. 2002. Genetic diversity and relationships among pea cultivars (Pisum sativum L.) revealed by RAPDs and AFLPs. Plant Breed 121: 429-435.

Singh KB, Singh S. 1991. Evaluation of exotic germplasm in lentil. J Agric Res 6 (2): 304-306.

Smith JSC, Smith OS. 1992. Finger printing crop varieties. Small holder production and processing of bioenergy as a strategy for an empirical law describing heterogeneity in the yield. Adv Agron 47: 85-140.

Togola A, Agbaka A, Agunbiade TA, Anato F, Chougourou DC, Nwilene FE. 2010. Connaissance paysanne des insectes foreurs de tiges du riz et leurs dégâts dans différentes zones écologiques du Bénin (Afrique de l'Ouest). Cah Agric 19: 262-266.

Vitale JD, Sanders JH. 2005. New markets and technological change in agriculture. Afr J Plant Soil 26 (2): 91-97.

Waddington H, Snilstveit B, Hombrados J, Vojtkova M, Philips D, Davies P, White H. 2014. Farmer Field Schools for improving Farming Practices and farmer Outcomes: A Systematic Review. Campbell Syst Rev 2014: 6. DOI: 10.4073/csr.2014.6. 